\title{
O sujeito de direitos
}

\section{Daniela Duarte Dias}

Universidade Federal do Rio Grande do Sul, Porto Alegre, RS Brasil.

\section{Lutiane de Lara}

Universidade Federal do Rio Grande do Sul, Porto Alegre, RS Brasil.

\section{Maria Cecília Butierres}

Universidade Federal do Rio Grande do Sul, Porto Alegre, RS Brasil.

É recorrente a compreensão de que o Direito moderno é um instrumento persecutório da paz social. $\mathrm{O}$ interesse do Direito, nesta perspectiva, é buscar regular a convivência social, uma vez que entende que o humano é gregário por natureza. No direito a noção de sujeito de direitos remete a um ser que é titular de direitos e deveres, possuindo uma relação jurídica com os outros sujeitos. Dessa forma, para que o Direito se exteriorize de forma a compor a convivência, objetiva-se em certo número de normas jurídicas. Essas normas são instituídas fundamentalmente pelo Estado. Diz-se 'fundamentalmente' porque o Estado não é o "criador único de normas jurídicas, porém é ele que condiciona a criação dessas normas, que não podem existir fora da sociedade política" (Diniz, 2000, p. 241).

Se na Idade Média o Direito era construído a partir dos interesses do Rei, baseado, portanto, na preocupação em manter a soberania dele, no século XVII e XVIII emerge uma nova mecânica de poder a partir da crítica à lógica do mando/obediência, presente na Soberania do medievo, o poder disciplinar. Este não suporá a existência física do soberano, mas transformará a soberania. Esta "nova" teoria da soberania e a organização do código jurídico que a deu sustentação permitiu ocultar os procedimentos e técnicas de dominação ao garantir o exercício dos direitos soberanos de cada um através da soberania do Estado. A organização do sistema jurídico permitiu uma democratização da soberania, pois constitui um direito público articulado com a soberania coletiva (Foucault, 2004).

Não se trata de um poder do soberano, mas de compreender o Estado como uma instância convergente de uma série de relações de poder que integra as forças existentes em uma sociedade. Assim, a soberania do Estado, e o Direito 
como seu correlato, pode ser entendido como uma força integradora das práticas de soberania exercidas pela sociedade. Ou seja, as normas jurídicas provem dos jogos de poder que estão presentes nesta suposta unidade que o Estado encarna. O Direito é efeito de lutas travadas na sociedade e não emana de um princípio de natureza humana.

O Estado como totalização é uma característica do dispositivo jurídicopolítico moderno. Um dispositivo que se articula e se estabiliza para a constituição do próprio sujeito (Macedo Jr, 1990). O Direito não é, portanto, apenas aquele instrumento que garante a convivência entre o sujeito de direitos, mas é propriamente quem o constitui. Este entendimento invalida a noção de natureza humana e direito natural presente nas formulações do Direito moderno.

$\mathrm{Na}$ característica formal do Estado de Direito de obediência ao princípio da legalidade, de modo que a ninguém é dado fazer ou deixar de fazer algo senão em virtude de lei, está presente a vontade de normatização da sociedade inerente ao Direito. Ele não apenas regula os comportamentos, mas dita os modos como devemos nos comportar e, nessa medida, forja a experiência de si. Historicamente, o Estado de Direito está atrelado às conquistas liberais do período das revoluções burguesas, as quais objetivavam fundamentalmente limitar a atuação do Estado absolutista em defesa das liberdades dos indivíduos e construir a noção individualista de indivíduo. A efetivação do Estado de Direito é um exemplo de como os ideais burgueses, hegemônicos na época, utilizaram o direito para garantir os interesses do nascente Estado moderno. O Direito e sua positivação normativa em leis são, portanto, formas institucionais de condução das pessoas a fins desejados, como forma de direcionar o convívio em sociedade - uma maneira de governar vidas.

A Constituição Federal de 1988, em seu artigo $1^{\circ}$, o qual versa sobre o Pacto Federativo, expressamente afirma que o Brasil constitui-se em um Estado Democrático de Direito. O Estado Democrático de Direito brasileiro tem como fundamento a soberania, a cidadania, a dignidade da pessoa humana, os valores sociais do trabalho e da livre iniciativa e o pluralismo político (Constituição Federal 1988, art. $1^{\circ}$ ). Nota-se, portanto, que a Constituição Brasileira não se limitou a caracterizar o Estado simplesmente como de Direito.

O Estado Democrático de Direito, reconhece os sujeitos de direito como autores e destinatários da lei e do 
provimento jurisdicional. Essa noção de Estado pressupõe uma aceitabilidade do Direito por todos, de modo que, fique assegurado o processo legislativo de acordo com a soberania popular, bem como haja o respeito ao sistema de direitos fundamentais. Os fundamentos de "cidadania, dignidade da pessoa humana e valores sociais do trabalho e da livre iniciativa" do Estado Democrático de Direito brasileiro remetem a ideia de um sujeito de direitos com ampla proteção social, através de políticas públicas sociais as quais garantam condições de uma vida digna e com condições para uma cidadania ativa, ou seja, participativa da esfera pública.

O Estado Democrático de Direito, portanto, traz em seu arcabouço uma série de questões que homogenizam, ao mesmo tempo, a experiência de si (noção de dignidade humana), os ideais a serem buscados (valores sociais do trabalho e da livre iniciativa e o pluralismo político) e condiciona estes princípios e normativas a todas as pessoas.

A ideia de um sujeito de direito e sua correlativa proteção social se torna complexa e até antagônica quando evidenciamos os jogos de poder presentes na democracia brasileira, em que é possível observar determinados segmentos da sociedade, os mais privilegiados, que usufruem seus direitos, não cumprem seus deveres e ainda, muitas vezes, lesam os direitos de outros segmentos menos privilegiados. Hoje, com raras exceções, apenas pessoas pobres ficam confinadas nos presídios por longos períodos, os jovens negros pobres estão entre o segmento que sofre mais violência, a violência policial amedronta principalmente aos (às) moradores (as) de periferia...

Contemporaneamente podemos pensar as políticas públicas como instrumento de garantia dos direitos. Um direito social que retrata o dever do Estado em garantir os direitos dos sujeitos, direito à saúde, educação, assistência, moradia, transporte, etc. Desta forma, o Direito não atua apenas normatizando o convívio entre os sujeitos, mas, conferindo deveres ao Estado. Elas, ao mesmo tempo em que garantem direitos, regulam e ordenam a vida dos sujeitos, seja através de prescrições sobre os modos de vida - ao normatizar o que é estar saudável, ao nos informar em que idade nos tornamos idosos, ou qual é a forma adequada de educar nossos (as) filhos (as), etc. Seja pela via do instituído pelo Estado, regulando as formas de participação política dos sujeitos, pois, se existe uma política pública para a saúde, a forma legal de se manifestar é nos conselhos de saúde 
e não nas ruas. As políticas públicas, neste campo de análise, são a manifestação da crescente preocupação biopolítica de normalizar a sociedade, como efeito da diminuição do recurso jurídico da lei no Estado.

Compreendemos, portanto, que a noção de sujeito de direitos deve ser problematizada em razão da complexidade inerente ao campo do direito para compreendermos o contexto do antagonismo entre o texto constitucional e o momento fático vivenciado pelo Brasil pós-surgimento da Constituição Federal de 1988. Podemos refletir sobre este antagonismo problematizando o contexto de construção das noções de Sujeito de Direitos, de Estado de Direito, de Estado Democrático de Direito, realizando uma desnaturalização destes. O movimento de desnaturalização é capaz de evidenciar que a construção dessas noções não é parte de uma evolução inerente ao processo civilizatório, mas efeitos de jogos de poder. A questão não seria os direitos e os deveres em si, mas como se constituem o Estado Democrático de Direito, a democracia e a própria noção de sujeito de direitos, quais relações essas noções produzem e quais são os efeitos dessa relação nos modos de experiência subjetiva.

\section{Referências}

Brasil. Constituição 1988. (1988) Constituição da República Federativa do Brasil: promulgada em 5 de outubro de 1988. Brasília, DF: Senado.

Diniz, Maria Helena.(2000) Compêndio de Introdução à Ciência do Direito. 12 ed. São Paulo: Saraiva.

Foucault, Michel. (2004) Microfísica do Poder. Rio de Janeiro: Edições Graal.

Macedo Jr., Ronaldo Porto. (1990) Foucault: o poder e o direito. Tempo Social; Rev. Sociol. USP, S. Paulo, 2(1): 151-176, 1.sem.

Daniela Duarte Dias, Lutiane de Lara e Maria Cecília Butierres: São doutorandas do Programa de Pós-Graduação em Psicologia Social e Institucional da UFRGS.

E-mail: lutianelara@yahoo.com.br; ddias@yahoo.com.br; cecíliabutierres@yahoo.com.br 